\title{
The NGO-isation of Arab Women's Movements
}

\section{Islah Jad}

\section{Introduction}

One of the dominant trends in the evolution of the Arab women's movements is a steady increase in the number of women's non-governmental organisations (NGOs) dealing with aspects of women's lives such as health, education, legal literacy, income generation and rights advocacy. This can be seen as a sign of the failure of centralised Arab states to bring about social change and development. Such NGOs are widely viewed as the development of an Arab "civil society", which can contain the authoritarian state, and as a healthy sign of real, "bottom-up" democracy in the region. On the other hand, they have also been viewed as a new and growing form of dependency on the West. Debates abound concerning the ideology of NGOs, their links both to their own states and to the states that fund them, and their utility for development and social change. These debates are given a new edge by signs that the current American government is giving greater attention than ever before to "democratisation" and "modernisation" of Arab societies and Arab regimes, through increased funding for civil society organisations. The US administration sees the role of women as vital in this respect.

This article traces the development of the Arab women's movements, with special attention to what I call their "NGO-isation". To shed some light on this trend, I examine the changing structures and discourses of Arab women's movements, in the context of a development discourse based in binaries such as West/East and state/civil society. The growing number of Arab NGOs in general, and women's NGOs in particular, must be seen in the context of a broader development trend that views NGOs as a vital vehicle for social change and democratisation. I will argue though that the NGO as a form of organisation is different in critical ways from another kind of organisation aimed at social change, namely the social movement. Analysing this difference is useful in revealing the limitations of NGOs in introducing genuine, comprehensive and sustainable development, and the social changes desired by local populations. This is not to say that the role of NGOs should be explained in terms of "conspiracy theory", but rather that they should be subjected to a more historical and empirical approach that does not take for granted their equivalence with "healthy" socio-political development.

\section{Arab women's organisations in historical context}

Many discussions about the proliferation and efficacy of Arab women's NGOs are contextualised in the dichotomy of West versus East. The West is seen by fundamentalist groups as a power which wants to impose its cultural values - especially individual freedom, materialism and securalism on the world. In contrast, Arab nationalists and leftists view the West as colonial and corrupting, buying the loyalties of the elites, whether political, social or economic, bringing to the foreground what Leila Ahmed calls 'colonial feminism' (Ahmed 1992: 163). Others set the proliferation of NGOs in a context of ongoing expansion of neo-liberalism, and the formation of a "globalised elite" (Hann and Dunn 1996; Edwards and Hulme 1992; Vivian 1994; Omvedt 1994; Petras 1997; Hanafi and Tabar 2002: 32-6), or as 'mitigating the class conflict, diluting class identities and culture, blurring the class borders and blunting the class struggle within nations and between them' (Qassoum 2002: 44-56).

With the region experiencing increasing Western economic and political intrusion, Arab women's movements emerged in the first half of the twentieth century amid two major political projects, independence and modernisation, stemming from secular nationalism and Islamic modernism respectively. While Islamic modernism aimed to 
rescue religion from narrow or erroneous interpretations, opening up Islam as a vital force in women's and men's daily lives, secular nationalism, articulated in the wake of colonial occupation, involved collective self-review as part of a project of national reinvigoration to win independence (Badran 1995; Baron 1994; Radwan 1998; Lazreg 1994).

Women were seen by the secular nationalists as an integral part of the "new nation"; and women themselves saw the realisation of their social rights as linked to future independent Arab states. In this context, Arab women formed organisations to enhance women's participation in the battles for independence, to defend their people and work to "advance" women in the realms of education, political participation and cultural life. Their organisations and unions were strongly supported by the emerging national and religious elite striving for independence and the advancement of their countries. The heroic role played by Algerian and Palestinian women in the battles to liberate their countries was one outcome of this phase in the growth of women's organisations.

Arab women's movements at that time were not isolated from the emerging international women's movements. Egyptian women, for example, were closely involved in the International Women's Suffrage Alliance, and the Egyptian Feminist Union (EFU) produced a journal in French, L'Egyptienne, aimed in part at altering the national image of Egypt abroad. Egyptian feminists also called in the international feminist forum for attention to the violation of the national rights of Palestinian Arabs, as well as convening an early international conference to support Palestinian women in their struggle against Zionism. This conference, 'Women of the Orient', attracted delegations from all over the Arab world and abroad, as well as a large Palestinian women's delegation (Zu'aytir 1980). International feminists were confronted with issues of imperialism that they may have preferred to ignore (Badran 1995: 13).

In Egypt, Algeria, Palestine and many other Arab countries, the "new woman" was deployed, and deployed herself, against the coloniser. "Authentic" dress and veiling did not constitute worrying issues at this time, and were not adopted by nationalist women as pressing strategies (Ahmed 1992; Badran 1995; Fleischmann 1999). Influenced by Arab socialism, many newly independent nations -
Egypt, Algeria, Iraq, Syria and Yemen - installed "state feminism", introducing economic and social policies aimed at integrating women in the labour market and the new nation (Kandiyoti 1991; Molyneux 1991; Moghadam 1993; El-Kholy 1998). Many women, especially those from poorer social strata, benefited from social rights such as free education, health and maternity services.

In contrast to the situation before independence, however, the newly emerging states showed strong hostility towards independent women's organisations, especially during the 1960s, which led to their banning (Egypt, Jordan), or their cooptation (Syria, Iraq, Algeria, Tunisia). The legacy of "populist authoritarianism" as an elite strategy for maintaining hegemony (Brumberg 1995: 230) endured despite the broad-based nature of independence struggles.

Arab women's experiences with their states vary from one nation to another. In most of the Gulf area, women's movements are still struggling to obtain basic political rights. In the states that claimed to be nationalist, socialist, or progressive, women suffered from the "Algerian syndrome", disappointment with state policies which did little or nothing to change women's status as "dependants" on male citizens. The state in most of these countries did little to change laws and penal codes that did not reflect changes in the situation and status of women, especially well-educated, professional women from the middle and lower middle classes. New restrictions on women's organisations were imposed, and women who participated in opposition political parties were "equally" targeted by state persecution and punishment. This led to the destruction or weakening of all forms of political and social participation, including political parties, workers', peasants', students' and women's unions. Some feminist voices arose in this period to denounce "Arab patriarchy" as the main obstacle to women's advancement.

From the mid-1970s, with most Arab states failing to achieve a sustainable level of development, or to absorb the increasing number of young people seeking employment, structural adjustment policies were widely adopted. This resulted in the almost complete withdrawal of the state from investment in the public sector, which led in turn to a severe deterioration of social and economic rights, translated in rising rates of unemployment and declining social 
welfare support from the state. In the longer term, this deterioration had a strong impact on women's status, illustrated by the UNDP's Arab Human Development Report 2002, which showed increases in women's illiteracy, unemployment, poverty and political marginalisation.

By the 1980s, when many Arab states were shaken by economic and social crises, most leaders successfully continued to evade domestic challenges, making only minimal response to demands for economic and political change. The collapse of the "communist bloc", traditional ally of many Arab states, contributed further to the retreat of progressive nationalism, at the same time as the Iranian revolution put an end to the regime of the Shah, bringing an Islamist religious leadership to power. Development within the region has also been held back by the increasingly aggressive policy of the state of Israel and the devastating destruction it has inflicted on countries like Lebanon and Palestine, and the consequent effects on ethnic separatist groups whether in Iraq, Sudan, Lebanon, or elsewhere (Jawad 2004). Against an increasingly bleak background of internal stagnation, external pressure increased on Arab countries to introduce more change, this time under the banner of a new development policy, "good governance", supported by the World Bank, the International Monetary Fund, the USA and many European donors.

This external pressure has ratcheted up very steeply in the wake of September 11th, with the increasingly aggressive policy of the USA, and its demonisation of Muslims in general and Arabs in particular. These have had negative effects of putting the whole region on the defensive, and forcing its peoples to adhere even more to a decaying status quo. The logic of "good governance" has become particularly important in underpinning US interventions in the region, with the military aggression to force regime change in Iraq being justified by a rhetoric of the need to "democratise". According to a recent news item, the current US administration views the many ills in Arab society as due to lack of democracy, and the inferior status of Arab women. US officials have said that their focus on democracy-building projects and the redirection of aid money to grassroots efforts can accomplish two things. One is to build the desire and ability to reform authoritarian governments, great and small. The other is to soften the image on the Arab street of the USA as a malign power whose only concern in the region is defending Israel, and thus preserving its access to cheap oil. After infrastructure and free trade, "democracy" tops the United States Agency for International Development's (USAID) regional agenda. ${ }^{1}$ The promotion of democracy and the rule of law includes activities intended to strengthen "civil society" and significant support to NGOs.

The USA's professed concern with democracy arouses the scepticism of many in the Arab world. Mustapha Kamel Al Sayyid, director of the Center for Developing Countries Studies at Cairo University, argues it would not be in US interest to promote true democracy in Egypt, since the only viable alternative to the present government is the Islamist opposition - a group known for its dislike of American policy. 'If the result of democratisation is that Islamists gain more voice in politics, then no doubt the US government will not, in practice, do much in the way of the real promotion of democracy' (cited in Lussier 2002).

The relation of NGOs to democracy is criticised from a number of perspectives. For example, the proliferation of NGOs is seen by some as the formation of a "globalised elite" in a context of ongoing expansion of neo-liberalism (Hanafi and Tabar 2002: 32-6), and by others as 'mitigating the class conflict, diluting class identities and culture, blurring the class borders and blunting the class struggle within nations and between them' (Qassoum 2002: 44-56). Important for women activists, however, is that this support by international actors, particularly the US government for women's organisations, and more generally for building up "civil society", serves to add yet more fuel to an already burning debate in the Arab world on the role envisioned and played by Arab NGOs, and women's NGOs in particular, in the process of development, democratisation and social change.

\section{Development and feminism: echoes of the colonial encounter}

These debates have to be examined with care, and take into consideration that external aid, whether from UN agencies or foreign governments, is seen in many Third World countries as a small portion of what was historically stolen from them, a continuation of the colonial encounter. The problem therefore is not in the aid itself, but rather in the way it is invested, to whom it is offered and how it 
can be brought under more democratic control.

Some Arab feminists suggest that 'what the colonists sought was to undermine the local culture' through 'colonial feminism' (Ahmed 1992). Like Lazreg, Ahmed is disturbed by the resemblance she perceives between colonial discourses and that of some contemporary Western feminists. She perceives them as devaluing local cultures and assuming that there is only one path to the emancipation of women, namely the path of 'adopting Western models' (Ahmed 1992; Lazreg 1994). On the other hand, Badran rejects such a position, arguing that 'attempts to discredit or to legitimise feminism on cultural grounds ... are political projects'. For her, the origins of feminism cannot be found in any culturally "pure" location: "External elements - external to class, region, country - are appropriated and woven into the fabric of the "indigenous" or local. Egypt, for example, has historically appropriated and absorbed "alien elements" into a highly vital indigenous culture' (Badran 1995: 31-2). She implies that Egyptian feminism is part of such an indigenous culture, underlining how women such as Hoda Sharawi and Ceza Nabarawi were more nationalist and uncompromising regarding British colonialism than men of their class. In spite of meeting with European feminists, and developing their ideas in relationship to European feminist organisations, Egyptian feminists were politically independent, expressing criticism of European support for Zionism. Further, their deepest concern was with the conditions of Egyptian and Arab women. Thus Egyptian feminists were very much part of, and concerned with, their own societies, and cannot be dismissed as Western (hence somehow inauthentic) agents.

Abu-Lughod further notes:

notions of separate cultures have themselves been produced by the colonial encounter. This leads to different possibilities for analysing the politics of East and West in the debates about women, ones that do not take the form of narratives of cultural domination versus resistance, cultural loyalty versus betrayal, or cultural loss versus preservation. It also opens up the possibility of exploring, in all their specificities, the actual cultural dynamics of the colonial encounter and its aftermath. (AbuLughod 1998: 16)
Drawing on her empirical study of the Egyptian women's movements, Al-Ali concludes that:

Egyptian women activists, as varied as they might have been in their ideological inclinations, were active agents in their specific cultural, social and political contexts. It never fails to astonish me how women activists continue to be discredited on the basis of their class affiliation and links to European culture and education, while male political activists, especially communists, do not seem to be exposed to the same degree of scrutiny concerning their class or educational background. (Al-Ali 1998: 121)

What can be concluded is that, in order to avoid falling into these cultural dichotomies, it is important to study - preferably empirically - the context in which these groups and organisations are working, what are their strategies, their form of organisations, their links to other social and political groups, to the state, and to powerful external agencies and their models of development.

Based on a number of empirical studies conducted on women's NGOs in Egypt, Palestine and in other Third World countries in Africa and Latin America, one can draw some tentative conclusions about the contextualised nature of these organisations. The rapid proliferation in the Arab world of issue-oriented groups, which is one way of defining an NGO, obliges us to ask how these groups should put the issues underlying their formation into a wider context; and, further, how the struggle for these issues (mostly related to social rights) is linked to a wider political, social and economic context. Putting women's issues into these contexts is important so as to identify what other social groups might join the struggle for change on any specific issue. But what we are seeing so far is that most Arab women's NGOs do not attempt a thorough analysis of, for example, the role of the state in allowing specific issues to persist; nor do they ask about its project for social change, or what the role of a wider women's and social constituency should be to achieve this change.

The Latin American experience supports the necessity for such analysis. Latin American women's movements have demonstrated that women's rights cannot be realised by pleading with an authoritarian state, nor by isolating women in women's organisations. By having their own organisations, 
then enlarging their constituencies, allying with political parties, and participating in the struggle for democratisation and political transition, Latin American women managed to mainstream their demands within state and society (Alvarez 1990; Molyneux 1996; Waylen 1996). These scholars have shown that women's organisations did not follow one path or strategy in their conflict with the state but rather a multifaceted approach that included many options.

An important point stressed by Waylen is that, in order to form political power, women's organisations need to link poor women's needs and interests with middle class women's interests. The concept of citizenship implies some commitment to the principle of equality, and to universal principles, but without assuming an undifferentiated public with identical needs and interests (Molyneux 1998: 84). The challenges of reconciling different class interests face Arab women's movements. The way that these challenges are met will depend partly on organisational structure. It is here that a differentiated and nuanced approach to the concept of "civil society" becomes necessary.

\section{The NGO-isation of Arab women's movements}

The formation of women's NGOs with particular social aims marks a very different form and structure for Arab women's activism from those that predominated in earlier periods. The early years of the twentieth century were characterised by the spread of women's literary salons, mainly for highly cultured and educated upper middle class women. Urban middle and upper class women also ran charitable societies, and later women's political unions, based on open membership for women. In Palestine for example, charitable societies recruited hundreds of women in their administrative bodies and general assemblies, while women's unions had large memberships extending to women in villages, and after 1948 in refugee camps. If we compare their reach with that of contemporary NGOs, one easily notes a decline in numbers.

The prevailing structure of NGOs, meanwhile, is that of a board of between seven and twenty members, and a highly qualified professional and administrative staff whose number is generally small, depending on the number and character of projects being dealt with. The power of decision is often not, as it is supposed to be, in the hands of the board, but usually in those of the director. The power of the latter stems from his or her ability to fundraise, be convincing, presentable and able to deliver the well-written reports that donors require. In order to achieve these requirements, communication and English language skills become essential. In some cases, an NGO director has the power to change board members, sometimes even without their knowledge. The highly professional qualities required of administrative staff for better communications with donors may not directly affect the links between an NGO and local constituencies, but most of the time it does.

Referring here to the Palestinian experience, the qualities of cadres in what were known as "grassroots organisations" - the women's committees that were branches of political formations that sustained the first Palestinian Intifada - differed considerably from those required in NGO staff. The success of the cadres lay in organising and mobilising the masses, and was based on their skills in building relations with people. They succeeded in this because they had a "cause" to defend, a mission to implement, and because they had a strong belief in the political formations to which they belonged. It was important for the cadre to be known and trusted by people, to have easy access to them, to care about them, and help them when needed. The task needed daily, tiring, time-consuming effort in networking and organising. These cadres knew their constituency on a personal level, and communication depended on face-to-face human contact.

NGOs, by contrast, depend mainly on modern communication methods such as media, workshops and conferences - globalised tools, rather than local ones. These methods may not be bad in themselves but they are mainly used to "advocate" or "educate" a "target group", usually defined for the period needed to implement the "project". Here the constituency is not a natural social group; rather it is abstract, receptive rather interactive, and the "targeting" is limited by the time frame of the project. This temporality of the project and the constituency makes it difficult to measure the impact of the intervention.

In this respect, the "targeting" policy is always limited, and implemented by professionals hired by the organisations to do the "job". This differentiates it from a 'mission' based on conviction and voluntarism. In addition, NGOs do not set organisation or mobilisation as goals. These 
differences between the structures and aims of NGOs and grassroots organisations do not help NGOs to act as mobilising or organising structures.

As for the internal governance of NGOs, a study of more than 60 Palestinian NGOs found that beside the marginal role played by their boards, most of their employees do not participate in the decisionmaking due to "their passivity or their lack of competence' (Shalabi 2001: 152). The "target" groups do not participate in decision-making or drawing up policy either. In many women's NGOs, the staff had nothing to do with the general budget of their organisation, and do not know how it is distributed. According to Shalabi, the internal governance of the surveyed NGOs was 'a mirror reflection of the Palestinian political system based on individual decision-making, patronage and clientelism', and the lack of rules organising internal relations in the organisation. In some cases a union dispute erupted, and was settled in a 'way very far away from the rule of law' (Shalabi 2001: 154).

It is important to notice these differences to help clarify the prevailing confusion between social movements and NGOs. In order to have weight or, in political terms, power, a social movement has to be based in large numbers. According to Tarrow, what constitutes social movements is that 'at their base are the social networks and cultural symbols through which social relations are organised. The denser the former and the more familiar the latter, the more likely movements are to spread and be sustained' (Tarrow 1998: 2). He adds that 'contentious collective action is the basis of social movements; not because movements are always violent or extreme, but because it is the main, and often the only recourse that most people possess against betterequipped opponents' (Tarrow 1998: 2).

The same can be said of women's movements. To put "women's movement" into context, we have to ask first, what a "women's movement" is and how can we distinguish it from "women in movement" (Rowbotham 1992 quoted in Jackson and Pearson 1998). To start with, there are contrasting views as to what a women's movement is. One kind of movement is that which mobilises to demand women's suffrage, has a leadership, a membership, and diffuse forms of political activity, as distinct from other forms of solidarity such as those based on networks, clubs or groups. According to Molyneux, a movement also implies a social or political phenomenon of some significance, due both to its numerical size, and to its capacity to effect change in some way or another, whether in the legal, cultural, social or political domains. A women's movement does not have to have a single organisational expression and may be characterised by a diversity of interests, forms of expression, and spatial location. In addition, it is made up of a substantial majority of women, when not exclusively made up of women (Molyneux 1998: 223).

Thus, it seems preferable to reserve the term "movement" for something larger and more effective than small-scale associations. Yet it is important to note that a large number of small associations, even with very diverse agendas, can in cumulative terms come to constitute a women's movement. In that case, it has no central coordinating body nor agreed agenda, although there will be common goals.

The long citations presented here are intended to shed light on the main elements that must be present in a movement if it is to achieve change. As I argued earlier, the typical structure of NGOs debars them from serving as mobilising or organising agents, so that however much they proliferate they cannot sustain and expand a constituency, or tackle issues related to social, political or economic rights on a macro or national level. Were they to undertake these aims, they would have to stop being NGOs.

NGO reliance on the use of media communication for advocating national issues (e.g. fraud in election, corruption) can lead to difficulties, pointing to the weakening effect of lack of a broad constituency. The cases of Sa'ad el-Dine Ibrahim, a seasoned defender of Egyptian "civil society", and of Eyad Sarraj, a prominent defender of Palestinian human rights, both jailed by their governments, need to be analysed for the light they shed on the efficacy of NGO as opposed to "movement" action. Big "issues" such as those they raised need an organised constituency to carry them, otherwise their actions are likely to be seen as stepping over a "red line", and drawing authoritarian punishment.

It is not easy, and perhaps not feasible, to assemble a number of women's NGOs to work towards a common goal - the minimum requirement for the definition of "women in movement". It appears that the NGO structure creates actors with parallel powers based on their recognition at the international level, and easy access to important national and international figures. But this international recognition is not translated into recognition or legitimacy on the local and national 
levels. This creates a competitiveness between NGO directors that makes it hard to compromise or agree on common goals, since the one who compromises may be seen as the weaker among power equals. Coordination is more possible between NGOs with similar aims, but it is difficult to achieve with women's organisations as different as charitable societies and grassroots organisations. NGO leaders, empowered by high levels of education, professional qualifications, and the international development "lingo", have a tendency to patronise the others.

These observations are supported by $\mathrm{NGO}$ studies in other Third World countries, where proponents of a "bottom-up" approach argue that the organisation of popular pressure and participation from below is a necessary prerequisite for political change and economic progress. They are also extremely sceptical about the ability and willingness of any regime to truly reform itself. Under such conditions, the "top-down" approach may simply be ineffective, as official donors have to work mainly through the governments of recipient countries. However, under such conditions, the "bottom-up" approach is also likely to fail, though for different reasons.

The potential of NGOs to foster participatory developments beyond the grassroots level is fairly small, given the transitory nature of projects. The activities of NGOs are typically project-focused; coordination between NGOs pursuing different aims is weak; and the potential to create change beyond narrowly defined target groups is uncertain at best. In any case, empowering the powerless from below is a time-consuming process. Most importantly, though, it is naive to assume that participatory development at the grassroots level can be significantly promoted in developing countries whose governments are notoriously unwilling to reform the political and economic systems. If governments are not reform-minded, they will suppress participatory developments wherever they emerge as soon as such developments threaten to undermine the power base of the ruling elites. The experience of NGOs in various countries offers ample evidence to this effect. The "bottomup" approach obviously relies on supportive measures by government authorities (Nunnenkamp 1995: 14-15).

One should raise here the question: are Arab governments willing to introduce reforms? Do they act to reform themselves? The evidence from Iraq, Egypt, Palestine, Saudi Arabia and other Arab countries suggest that they are not, and do not. The appearance of the wives of presidents and rulers, princesses, and prominent women in certain women's NGOs cannot be translated as a willingness to reform, but means rather that women's rights and claims are seen as apolitical and politically unthreatening, since they do not touch the political, economical and social foundations of the Arab regimes.

In this article, I have argued that the role attributed by UN agencies and international development organisations to Arab women's NGOs as a vehicle for democratisation and participatorybased development needs to be re-assessed through empirical studies, and not pursued on the basis of the old dichotomies of West versus East. The Arab women's NGOs in their actual forms and structures might be able to play a role in advocating Arab women's rights in the international arena, provide services for certain needy groups, propose new policies and visions, generate and disseminate information. But, in order to affect a comprehensive, sustainable development and democratisation, a different form of organisation is needed with a different, locally grounded vision and a more sustainable power basis for social change.

\section{Note}

1. Washington Post, 4 November 2002. 


\section{References}

Abu-Lughod, L., 1998, Remaking Women - Feminism and Modernity in the Middle East, Princeton, New Jersey: Princeton University Press, Princeton

Ahmed, L., 1992, Women and Gender in Islam, New Haven and London: Yale University Press

Al-Ali, N.S., 1998, 'Standing on shifting ground: women's activism in contemporary Egypt', PhD dissertation, Department of Anthropology, School of Oriental and African Studies, University of London

Alvarez, S.E., 1990, Engendering Democracy in Brazil: Women's Movements in Transition Politics, Princeton, New Jersey: Princeton University Press

Badran, M., 1995, Feminists, Islam, and Nation: Gender and the Making of Modern Egypt, Princeton, New Jersey: Princeton University Press

Baron, B., 1994, The Women's Awakening in EgyptCulture, Society and the Press, New Haven and London: Yale University Press

Brumberg, D., 1995, 'Authoritarian Legacies and Reform Strategies in the Arab World', in R. Brynen, B. Korany and P. Noble (eds), Political Liberalisation and Democratisation in the Arab World, London: Lynne Rienner Publishers

Edwards, M. and Hulme, D. (eds), 1992, Making a Difference: NGOs and Development in a Changing World, London: Earthscan Publications

Fleischmann, E., 1999, 'The Other "Awakening": The Emergence of Women's Movements in the Modern Middle East, 1900-1940', in M. Meriwether and J. Tucker (eds), A Social History of Women and Gender in the Modern Middle East, Boulder, Colorado: Westview Press

Hanafi, S. and Tabar, L., 2002, 'NGOs, elite formation and the second Intifada', Between the Lines, Vol II No 18, October, Jerusalem

Hann, C. and Dunn, E., 1996, Civil Society: Challenging Western Models, London: Routledge

Jackson, C. and Pearson R. (eds), 1998, Feminist Visions of Development: Gender Analysis and Policy, London and New York: Routledge

Jawad, S.A., 2003, 'Why Israel pushes for the strike against Iraq', Between the Lines, Vol III No 21, March, Jerusalem

Kandiyoti, D., 1991, Women, Islam and The State, London: Macmillan Press

El-Kholy, H.A., 1998, 'Defiance and compliance: negotiating gender in low-income Cairo', unpublished PhD thesis, School of Oriental and African Studies, University of London

Lazreg, M., 1994, The Eloquence of Silence: Algerian Women in Question, New York: Routledge

Lussier, A.M., 2002, 'Aid to trade to democracy?', Cairo Times, Vol 6 Issue 37, 21-27 November

Moghadam, V., 1993, Modernizing Women: Gender and Social Change in the Middle East, Boulder, Colorado: Lynne Rienner Publishers

Molyneux, M., 1998, 'Analyzing Women's Movements', in C. Jackson and R. Pearson (eds), Feminist Visions of Development: Gender Analysis and Policy, London and New York: Routledge

Molyneux, M., 1996, 'Women's Rights and the International Context in the Post-communist States', in M. Threlfall (ed.), Mapping the Women's Movement: Feminist Politics and Social Transformation in the North, London: Verso

Molyneux, M., 1991, 'The Law, the State and Socialist Policies with Regard to Women: The Case of the People's Democratic Republic of Yemen 1967-1990', in D. Kandiyoti (ed.), Women, Islam and the State, London: Macmillan Press

Nunnenkamp, P., 1995, 'What donors mean by good governance: heroic ends, limited means, and traditional dilemmas of development cooperation', IDS Bulletin, Vol 26 No 2: 9-16

Omvedt, G., 1994, 'Peasants, dalits and women: democracy and India's new social movements', Journal of Contemporary Asia, Vol 24 No 1: 35-48

Petras, J., 1997, 'Imperialism and NGOs in Latin America', Monthly Review, Vol 49 No 7, December, www.monthlyreview.org/1297petr.htm, accessed 20 March 2004

Qassoum, M., 2002, 'Imperial agendas, "civil society" and global manipulation Intifada', Between the Lines, Vol III No 19, December, Jerusalem, www.between-lines.org, accessed 5 March 2004

Radwan, E.S., 1998, 'Jurisprudence and women: reformist and traditional', Bahithat, Lebanese Association of Women Researchers, Fourth Issue: 1997-1998, Beirut, Lebanon

Rowbotham, S., 1992, Women in Movement: Feminism and Social Action, New York and London: Routledge

Shalabi, Y., 2001, 'al-ta'thirat al-dawleya 'ala tahdid ro'aa al-monathmat ghayr al-hokomeyya alfelastineyya wa-adwareha' (International and local impacts on the visions and roles of 
Palestinian NGOs), MA thesis, Bir Zeit University, Palestine

Tarrow, S., 1998, Power in Movement: Social Movements and Contentious Politics, Cambridge Studies in Comparative Politics, Cambridge: Cambridge University Press

UNDP, 2002, Arab Human Development Report 2002,

New York: United Nations Development Programme (UNDP)
Vivian, J., 1994, 'NGOs and sustainable development in Zimbabwe: no magic bullets', Development and Change, Vol 25 No 1: 167-93 Waylen, G., 1996, Gender in Third World Politics, Buckingham: Open University Press

Zu'aytir, A., 1980, Yawmiyyat Akram Zu'aytir: alharaka al-wataniyya al-Filastiniyya 1935-1939, Beirut: Palestine Studies Association 